\title{
Women and Social Media: How Face Threatening Acts of Female Indonesian Instagram Users be Portrayed?
}

\author{
Monika Sri Yuliarti ${ }^{1}$, Likha Sari Anggreni ${ }^{2}$, and Prahastiwi Utari ${ }^{3}$ \\ Faculty of Social and Political Sciences, Universitas Sebelas Maret, Surakarta, Indonesia ${ }^{1,2,3}$ \\ \{monika.yuliarti@staff.uns.ac.id ${ }^{1}$, likhasari@staff.uns.ac.id², prahastiwi@staff.uns.ac.id ${ }^{3}$ \}
}

\begin{abstract}
Politeness is a norm in society that functions to maintain harmony between individuals in the society. Currently, the development of information and communication technology enables a shift in social interaction from direct human interaction to online interaction through a media, like social media. Without politeness, there will be a chaos, and one of which that appears more often nowadays is cyberbullying. The politeness phenomenon in this online interaction can be seen from the interactions that occur in social media, with Instagram as one of the platforms that increasingly more popular recently. In the context of the use of social media, it appears that the number of female users is higher than men. Not only in term of the number of the user, women also be found as more crowded in social media than men. This study aims to explore how politeness representation, specifically relates to Face Threatening Acts (FTA) in online interactions among female users of Instagram accounts. The politeness theory by Penelope Brown and Stephen Levinson is used as a basis for dissecting the phenomenon that is being studied. Politeness theory explains how small variations in the way we say something are related to the wider features of social relations and social contexts. This helps us understand how individuals create and interpret messages and also offer accounts for the use of the language of the speaking community. In this matter, the term positive face and negative face established, which lead to FTA. Politeness theory consists of various strategies for committing FTA which are Bald-on-record strategies and Off-record strategies. It is a descriptive qualitative study about FTA in online interaction, particularly between women Instagram users. It is a literature study that is hoped can enrich the conceptual study about politeness in online interaction using social media. The data collection techniques in this study is document studies, with the source of data are reference about the research topic from journal articles or handbook. The expected findings from this study are the presence of FTA patterns on social media, especially among women. The implication of this study is that there are guidelines for further conducting studies that are able to find the background and reasons why female Instagram users apply or not apply the FTA.
\end{abstract}

Keywords: Face Threatening Act; Politeness theory; Instagram; online interaction; female; politeness 


\section{Introduction}

In a society. To have a harmonious life, there must be some rules to govern the interaction between the people, which also be understood as social norms. Interaction between humans is a place where humans can be connected to one another. In these conditions, many things are very possible to happen, one of which is the emergence of conflict. Associated with the emergence of conflicts that occur in social interaction, the ability to establish relationships is very necessary, even from childhood. Apart from being something that arises as a result of social interaction, conflict is also seen as an important part of social interaction it self (Sims, Hutchins, \& Taylor, 1997)[1].

Without the norms, miscommunication is possible to happens. In social life, we know there are many kinds of norms. One of the social norms is the politeness norm that has lately faded, one of them due to the development of the times. The change of politeness norms often causes unpleasant things to happen. Although this violation of politeness norms is manifested in actions which are considered to be small and of no value, the effects are extraordinary. This can be seen from the case of clashes between villages that occurred in Buton, Sulawesi, last June. The tribunnews online news portal reports on the feud between the residents of the village of Sampoabalo and the village of Gunung Jaya, which was caused by a motorcycle convoy carried out by the youths of the village of Sampoabalo who passed through Gunung Jaya Village around 9 pm (Jyestha, 2019)[2]. Violation in the norms of politeness also cause a brawl between residents of Kaliwlingi village, and Sawojajar village, Brebes. That was caused by mocking of each other on social media (Jawapos.com, 2017)[3].

On the other hand, there is a change in social interaction, from face to face to mediated communication using social media. In the context of communication using social media, the shifting of politeness norms allows cyberbullying. Cyberbullying has become an important issue in the global scope that requires serious attention. The emergence of internet technology followed by the development of social media platforms has made it possible to increase cyberbullying. Social media users can abuse each other even more because of the anonymity on social media. Data from Ipsos, a research agency based in Paris, shows that there was 9 percent increase in global awareness of cyberbullying from 2011 to 2018 . In terms of children as cyberbullying victims, 33 percent of parents' worldwide report that they witness a child in their community had been cyberbullied in 2018, up from 26 percent in 2011. Meanwhile, 17 percent of the parents say that their own child had experienced cyberbullying in 2018 and mostly it happened in social network sites (Newall, 2018)[4]. Beside the children, teens and adults also had been reported to experienced cyberbullying. Pew Research Center reported that $59 \%$ of US teens have been bullied or harassed online (Anderson, 2018)[5], and $40 \%$ of adults have been being bullied in a cyber space (Duggan, 2017)[6].

Furthermore, this phenomenon of cyberbullying also occurs in Indonesia. UNICEF reported that in 2016, Indonesian teens who experienced cyberbullying reached $50 \%$ (Harususilo, 2018)[7]. Many scholars have already defined the term of cyberbullying. One of them is Agatston that is cited by Circello. It is said that cyberbullying is the use of social media network sites or other digital technologies such as cell phones and personal pagers to be cruel or harassing others (Circello, 2013)[8].

The phenomenon above is needed to be solved. To understand how to deal with the phenomenon, it is important to think about an alternative of solution. Politeness is considered as the answer of the problem, since cyberbullying involves some negative things that can be prevented by the politeness norm. Therefore, it is needed to be passed down from generation to generation. The socializing of politeness sometimes faces obstacles because the storytelling 
process that is generally found in the socialization is no longer quite popular today, due to changes in the style of communication between generations. The generation gap that occurs allows the method of socialization of politeness values run with less than optimal.

In Malaysia, for example, the storytelling to socialize social cultural values no longer be done using traditional storytelling that only involves face to face and direct human communication, but by involving technology of communication. Zin and her colleagues found that 2D animation application, namely MyEdu Tale has been succeeded in promoting sociocultural awareness among children age 5 to 12. It shows that there is a new form of socializing a value rather than just a conventional storytelling (Zin, Nasir, \& Ghazali, 2010)[9]. Moreover, storytelling with additional property also popular in Indonesia, like hand puppet, plants, artificial things, or comic book (Putri, 2017)[10].

More specifically, online interaction between female in social media has been becoming an interesting subject to be studied. A study that is conducted by Huang \& Chou found that gender became of the factors in student cyberbullying in Taiwan, and female dominated male (Huang \& Chou, 2010)[11]. Along with it, Marcum and her colleagues found that women are more likely than men to send online gossip about other people to hurt them (Marcum, Higgins, Freiburger, \& Ricketts, 2012)[12].

In term of the platform of social media, in Indonesia, it seems that Facebook is still becoming the most famous social media among others. However, there is a data about the users of Instagram in Indonesia that was quite interesting. Discount portal from Indonesia CupoNation, recently conducted a study of users of social media and popular applications used by Indonesians. Based on this study, Indonesia became the 4th country with the largest Instagram and Facebook users in the world. CupoNation data published in the online portal Liputan6.com say that so far, America has become the country with the most Instagram users. In total there are 110 million Instagram users in America. While Brazil occupies the second position most Instagram users with 66 million users. The third country that has the most Instagram users is India with 64 million users. While Indonesia which is in the 4th position has 56 million Instagram users (Wardani, 2019)[13]. Based on the explanation above, this study is eager to examine the politeness norms in online interaction of Indonesian female social media users, especially in Instagram, considering that social media has now become a public sphere that complements or to a certain extent changes direct communication between humans

\section{Method}

It is a qualitative descriptive study, so the data used in this study are in the form of words and sentences, without any calculations and numbers in them. This research is a review of literature about the concept of face threatening act which is part of politeness study. Therefore, the analysis unit of this research is the phenomenon about it with some of the analysis about the background, reason, and the application of this concept in the social, as part of social media platform.

The data collection technique employed in this study is documents study. According to Kartodirdjo who was cited by Bungin, documents not only consisted of things that were printed such as autobiographies, personal letters, diaries, clippings, government documents and personal documents, romantic stories or general stories, but also photos, discs, hard disks, video recording, movies, data on the server/ flashdisk, and data stored on the web site 
(Bungin, 2008)[14]. In the context of this study, the documents that were used as the data were journal articles, textbooks, and content of Instagram that fit to the theme of the study.

This study began with the search of the references about politeness, especially from the scientific journal articles related to politeness. In general, the topic of politeness is widely researched in the context of direct interaction, and in general there has not been much study on this matter from a gender perspective. Journal articles about politeness are dominated by studies related to culture. Furthermore, a search was made for the concept of politeness, especially the theory of politeness that was conceived by Goffman, which was later developed by Brown and Levinson. The study of politeness theory is focused on the concept of face threatening act (FTA). After conducting an assessment of the concept of FTA, further searches related to social media and women were carried out, bearing in mind that this study focused on FTA conducted by women on social media, and the last part is an assessment of online interactions between women on Instagram, especially those that might indicate an FTA

\section{Result and Discussion}

\subsection{Politeness in Everyday Life}

As one of the social norms, politeness is a tool that can be used to maintain harmony in human life. Community norms are the embodiment of values, good/ bad measures, which are used as directors, guidelines, encouragement of human actions in shared life (Parmono, 1995)[15]. Based on this definition, it can be seen that politeness is closely related to culture. The politeness that applies in one region will be different from the politeness that originates in another area.

Politeness in daily life allows the involvement of other concepts that relates to the politeness itself, one of which is etiquette. Etiquette plays a role in behavior as a determinant of rules in politeness, namely negative politeness rule and positive politeness rule (Ryabova, 2015)[16]. In negative politeness rules, someone tends to ask other parties to do something for him. On the contrary, in a positive politeness rule, a person will involve himself in what is revealed to others, so that he will do what he says or commands. For example when you want to close the door of a room, a negative politeness rule usually uses the phrase, "will you shut the door, please?"; Meanwhile, in the positive politeness rule, the sentence used for example, "I think we should shut the door".

Moreover, Ryabova found that politeness strategy can be understood in several kinds, like absolute politeness, relative politeness, negative politeness, and also positive politeness. The kinds of politeness require an exact form of speech act etiquette. Ryabova also found that politeness strategy can be anaylzed by speech act like condolences and speech acts through the pragmatic structure (Ryabova, 2015)[16].

Based on the study conducted by Syabova, it can be seen that words are one of the things that indicates politeness in daily life. It shows that politeness is important in communication between humans, because communication involving words, which is also called verbal communication.

Besides being able to be analyzed based on words verbally, politeness can also be known from the manner in speaking and listening that is carried out in everyday conversation carried out in a casual context. This is consistent with studies conducted by Kitamura (Kitamura, 2000)[17]. Kitamura's study shows that politeness is crucial in interactions between people, because there are elements of speaking and listening, where both activities require interaction 
between two or more people. This shows that the harmony of society can be easily achieved if everyone understands and lives the norms of decency in everyday life.

Politeness is not only needed and arises in social interactions, but also in online interactions. This is something that cannot be avoided in today's life, where the internet is becoming a common thing, and is becoming a new culture among the people of the world, so that online interaction is also inevitable.

Online interaction related to politeness, one of which can be found in interactions between users of social media related to political issues. Nurfaida found in her study that social media user acceptance of government policy could be seen in her politeness by reviewing comments that were a response to the government policy. By reviewing social media user comments, in this case Instagram, political issues, which are related to politics, are no longer discussed in official and limited forums, but have become a topic of discussion in the context of daily life (Nurfarida, 2016)[18].

Furthermore, aside from social media, online gaming has also become a phenomenon that is increasingly developing today. This is also important if it is associated with norms of decency, one of which is the amount of cyber bullying that occurs in online games, including those committed by teenagers and children. A study conducted by Ko \& Ko on politeness among students when they played the online game Second Life produced findings that politeness can be seen through the interaction between these online game players in the form of their conversations and exchanging messages or comments (Ko \& Ko, 2018)[19].

In Nurfarida and Ko \& Ko's study it can be seen that politeness in online interactions can be studied through written verbal words. This happens because in online interactions there are channels that connect the communicator with the communicant, so that the interaction that occurs is not a direct interaction that can involve spoken verbal elements. Conversely, in online interactions, verbal words involved are verbal words written because participants in these online interactions exchange messages with written messages on certain social media. Some studies related to politeness in daily life include direct interaction between human beings as well as online interactions contained in media communication between humans.

\subsection{Face Threatening Act in Politeness Theory}

Brown and Levinson in Kitamura introduce the term 'face' to explain 'politeness' in a broader scope. It means that when people interact with others, they will manage their face, either positive or negative face. By positive face, it means that a positive and consistent image people have of themselves and their need for an approval from the communicant, while negative face means that there is a claim about territories, personal preserve, and a right relates to non-distraction (Kitamura, 2000)[17]. Relates to the faces in politeness study, there are also positive and negative politeness that can be understood in different way. Positive politeness can be understood by the similarities among the participants in an interaction and also by showing appreciation on the self-image of the interlocutor. Meanwhile, saving the interlocutor's 'face' by mitigating face threatening acts, such as advice-giving and disapproval and showing respect for the addressee's right not to be imposed on were the indication negative politeness has happened.

A concept elaborated by the originators of Politeness Theory, Penelope Brown and Stephen Levinson, the Face-Threatening Act (FTA) is considered an appropriate concept to uncover this problem. FTAs are actions that violate the need for communication targets to be respected and respected. There are 4 politeness strategies that can be applied in the context of 
wanting to see online interactions that occur on social media, namely: off record, negative politeness, positive politeness, and on record baldly (Littlejohn, Foss, \& John, 2016)[20].

Moreover, Brown and Levinson as cited in Cutrone explains several factors that maybe involve in FTA, which are the social distance between the participants that are involved in an interaction, the power that owns by the participants, which is also based on their roles to each other. The last factor that determine FTA is the absolute ranking of imposition in a particular culture (Cutrone, 2011)[21].

Amundrund studie's about face threatening act postulates three kinds of the way to avoid face threatening act during the interaction, which are requests, apologizes, and complaints. Ellis, as cited by Amundrund describes requests are the efforts that are done by someone or communicator so that the partner or communicant do or not to do something for the communicator's sake. Meanwhile, apologies can be considered a face-saving act because they entail the speaker taking responsibility for some action or lack thereof. Olshtain and Cohen as cited by Amundrund explained the central statement of apology, and elaborations such as explanations, acknowledgements, or offers of repair as apologies strategy. Lastly, complaints are part of FTA that contains a censure from the speaker about some acts that gives a bad effect for her or him, as explianed by Trosborg in Amundrund's work (Amundrund, 2012)[22].

Based on Amundrund's study, it can be seen that in fact the three things that have been explained above, namely requests, apologizes, and complaints are strategies that can be applied in daily communication between people. However, applications in daily life may differ from one communicator to another. However, as long as these three things can be done, of course, FTA can be minimized.

\subsection{FTA in Online Interaction between Women in Social Media}

The women's group is an interesting group to study, considering that some previous studies noted that there are differences in the use of new media between men and women. A study in Lebanon by Daher shows that the women there have provided examples that their use of social media has changed the context of traditional roles of women in society, penetrated online patriarchy that is usually done by men, and brought up leaders women as decision makers (Daher, 2016)[23]. In relation to the use of social media, women are indeed not the most dominant group, because in quantitative terms, there are more male social media users compared to women. However, women have more activity compared to men, in using social media. This has become natural, given that psychologically, women are known as a group that has greater verbal ability compared to men. They are generally known to speak faster when they are babies compared to men who generally can walk faster than they can talk.

What's interesting about this is, a psychologist, Nurhayati stated that this, related to the ability of women verbally, is not something that can be proven academically, so he called it a female psychological bias. Besides verbal ability, another woman's psychological bias according to Nurhayati is that women are known to be emotional and cry more easily when compared to men. Finally, the psychological bias of women is that psychological women always succumb, approve, adjust, and please others (Nurhayati, 2012)[24]. The latter psychology bias is in accordance with the context of this study. Based on this explanation, women psychology actually involves rude, assertive, fighting, and aggressive behavior, including verbal aggression. This is often found in discussions among women through mass media, in certain uploads. For example on the Instagram account @ lambe turrah, especially in uploads related to female artists with controversies, for example singer Mulan Jameela who holds the title of "actor" for quite a long time (someone who seizes someone else's husband). 
The negative title is inherent until now, and it all started with the interaction of the followers of the@lambe turrah account when commenting on his upload about Mulan Jameela. Nothing was applied regarding the FTA, namely requests, apologies, and complaints..

\section{Conclusion}

Based on the concepts that have been presented regarding politeness and FTA, it can be concluded that FTA has not been applied much in online interactions using Instagram conducted by women. The conclusion in this literature review is expected to be the basis for FTA research in online interactions between women with more specific cases and in-depth discussion, including the reasons, influencing factors, and the impact resulting from heeding FTA strategies in online interaction.

\section{References}

[1] Sims, M., Hutchins, T., \& Taylor, M. (1997). Conflict as social interaction: Building relationship skills in child care settings. Child and Youth Care Forum, 26(4), 247-260

[2] Jyestha, V. (2019, 06 07). Kronologi Bentrok Antar Warga Desa di Buton, Konvoi Sepeda Motor Picu Tawuran. Retrieved 08 10, 2019, from tribunnews.com: https:/wartakota.tribunnews.com/2019/06/07/kronologi-bentrok-antar-warga-desa-dibuton-konvoi-sepeda-motor-picu-tawuran?page $=4$

[3] Jawapos.com. (2017, September 27). Jawapos.com. Retrieved August 08, 2019, from jawapos.com: https://www.jawapos.com/jpg-today/27/09/2017/tawuran-antar-2-desapecah-pak-kades-luka-parah/

[4] Newall, M. (2018, June 27). Global Views on Cyberbullying. Retrieved August 9, 2019, from Ipsos: https://www.ipsos.com/en/global-views-cyberbullying

[5] Anderson, M. (2018, September 27). A Majority of Teens Have Experienced Some Form of Cyberbullying. Retrieved August 10, 2019, from Pew Research Centre: https://www.pewinternet.org/2018/09/27/a-majority-of-teens-have-experienced-someform-of-cyberbullying/

[6] Duggan, M. (2017, July 11). Online Harassment 2017. Retrieved August 09, 2019, from Pew Research Centre: https://www.pewinternet.org/2017/07/11/onlineharassment-2017/

[7] Harususilo, Y. E. (2018, October 08). COMIC 2018 Melawan Perundungan Siber. Retrieved August 2019, from Kompas.com: https://edukasi.kompas.com/read/2018/10/08/10570981/comic-2018-melawanperundungan-siber

[8] Circello, M. G. (2013). Influences of the Misuse of Social Media on the Evolution of Adolescent Cyberbullies. Rochester: St. John Fisher College.

[9] Zin, N. A., Nasir, N., \& Ghazali, M. (2010). Promoting Socio-Cultural Values Through Storytelling Using Animation and Game-Based Edutainment Software. In M. Crisan, Convergence and Hybrid Information Technologies (pp. 209-226). Rijeka: Intech.

[10] Putri, H. (2017). Penggunaan Metode Cerita untuk Mengembangkan Nilai Moral Anak TK/SD. Muallimuna Jurnal Madrasah Ibtidaiyah, 3(1), 87-95 
[11] Huang, Y. Y., \& Chou, C. (2010). An analysis of multiple factors of cyberbullying among junior high school students in Taiwan. Computers in Human Behavior, 26(6), 1581-1590.

[12] Marcum, C. D., Higgins, G. E., Freiburger, T. L., \& Ricketts, M. L. (2012). Battle of the sexes: An examination of male and female cyber bullying. International Journal of Cyber Criminology, 6(1).

[13] Wardani, A. S. (2019, June 26). Jumlah Pengguna Instagram dan Facebook Indonesia Terbesar ke-4 di Dunia. Retrieved July 22, 2019, from liputan6.com: https:/www.liputan6.com/tekno/read/3998624/jumlah-pengguna-instagram-danfacebook-indonesia-terbesar-ke-4-di-dunia

[14] Bungin, M. B. (2008). Penelitian Kualitatif; Komunikasi, Ekonomi, Kebijakan Publik, dan Ilmu Sosial Lainnya. Jakarta: Kencana.

[15] Parmono. (1995). Nilai dan Norma Masyarakat. Jurnal Filsafat, 23(November), 20-27.

[16] Ryabova, M. (2015). Politeness Strategy in Everyday Communication. Procedia Social and Behavioral Sciences, 206, 90-95

[17] Kitamura, N. (2000). Adapting Brown and Levinson's 'Politeness' Theory to the Analysis of Casual Conversation. ALS2k, the 2000 Conference of the Australian Linguistic Society (pp. 1-10). Melbourne: Australian Linguistic Society.

[18] Nurfarida, I. (2016). Analysis of Politeness Communication in Instagram: Study of Language Use in Social Media. Proceedings of International Conference on Language, Literary and Cultural Studies (ICON LATERALS) 2016 (pp. 779-791). Malang: Universitas Brawijaya

[19] Ko, L.-Y., \& Ko, L.-Y. (2018). How Polite You Are: A Study of Learners' Politeness Strategies Used in Avatars in the Second Life Virtual World. Journal of Education \& Social Policy, 5(4), 167-173

[20] Littlejohn, S. W., Foss, K. A., \& John , O. G. (2016). Theories of Human Communication eleventh edition. Long Groove: Waveland.

[21] Cutrone, P. (2011). Politeness and Face Theory: Implications for the Backchannel Style of Japanese L1/L2 Speakers. Language Studies Working Papers, 3, 51-57.

[22] Amundrund, T. (2012). Face-Threatening Acts (FTAs) in Advanced Non-Native English Speaker. Bull. Nara Univ. Educ., 61(1), 183-190

[23] Daher, M. (2016). Women Empowerment through Technology and Social Media. Lebanese American University. Retrieved from http://mepitl.lau.edu.lb/images/MiraDaher_WomenEmpowermentThroughTechnology AndSocialMedia.pdf

[24] Nurhayati, E. (2012). Psikologi Perempuan dalam Berbagai Perspektif. Yogyakarta: Pustaka Pelajar.. 